\title{
The earliest fully brachypterous auchenorrhynchan from Cretaceous Burmese amber (Homoptera: Fulgoroidea: Jubisentidae)
}

\author{
Аревнейшая џикадка с сильно укороченными крыльями из \\ мелового бирманского янтаря (Homoptera: Fulgoroidea: \\ Jubisentidae)
}

\author{
Dmitry E. Shcherbakov \\ A.E. Щербаков
}

Borissiak Paleontological Institute, Russian Academy of Sciences, Moscow, Russia; dshh@narod.ru. Палеонтологический институт им. А.А. Борисяка РАН, Москва, Россия.

KEY WORDS: planthoppers, Perforissidae, wing dimorphism, brachyptery, sensory pits, phylogeny, fossil, host plants, grasses, camouflage, mimicry.

КЛЮЧЕВЫЕ СЛОВА: носатки, Perforissidae, крыловой диморфизм, короткокрылость, сенсорные ямки, филогения, ископаемые, кормовые растения, травы, маскировка, мимикрия.

ABSTRACT. Psilargus anufrievi gen. et sp.n. (Psilarginae subfam.n.) from mid-Cretaceous Burmese amber is assigned to the family Jubisentidae in basal (pre-cixioid) Fulgoroidea. The two formerly known genera of this family are placed in Jubisentinae stat.n. The only known specimen of the new species is a minute female with extremely shortened wings. It is the earliest recorded instance of extreme brachyptery in Auchenorrhyncha. All known Jubisentidae were flightless, camouflaged, and likely associated with herbs in the Burmese Cretaceous tropics.

PЕЗЮME. Psilargus anufrievi gen. et sp.n. (Psilarginae subfam.n.) из среднемелового бирманского янтаря отнесён к семейству Jubisentidae среди примитивных (до-циксиоидных) Fulgoroidea. Два ранее известных рода этого семейства помещены в Jubisentinae stat.n. Единственный известный экземпляр нового вида - мелкая самка с сильно укороченными крыльями. Это древнейший отмеченный случай резкой короткокрылости у Auchenorrhyncha. Bсе известные Jubisentidae были нелетающими, обладали маскировкой и, вероятно, обитали на травах в бирманских меловых тропиках.

The mid-Cretaceous Burmese amber (ca. $100 \mathrm{Ma}$ ) is a real Aladdin's cave for paleoentomologists. This fossil resin was produced by araucarian trees in a rainforest [Poinar et al., 2007; Poinar, Buckley, 2008] on an island in the tropical Tethys Ocean between Gondwana and Laurasia [Westerweel et al., 2019], far from other Cre- taceous Lagerstätten. Among many wonderful and unexpected insect taxa, three endemic planthopper families have recently been discovered in Burmese amberDorytocidae, Yetkhatidae and Jubisentidae [Emeljanov, Shcherbakov, 2018; Song et al., 2019; Zhang et al., 2019]. In the Burmese amber fauna these groups coexist with widespread Cretaceous families, such as Perforissidae [Shcherbakov, 2007a; Zhang et al., 2017] and Mimarachnidae [Shcherbakov, 2007b, 2017; Luo et al., 2020 ; etc.], and several extant families, such as Cixiidae and Achilidae [Shcherbakov, 2000; Szwedo, 2004] making up a rich and diverse planthopper assemblage [Perkovsky et al., 2019]. The latest find, recently offered on eBay, is an unusual brachypterous female planthopper described below as a new genus and subfamily of Jubisentidae.

The two Cretaceous planthopper families known from adults, Perforissidae and Mimarachnidae [Shcherbakov, 2007a, b] are referred to the basal, precixioid Fulgoroidea on account of having setigerous hind tibial pectens and the proximal $\mathrm{CuA}$ fork in the tegmen. The two other Cretaceous families based on nymphs with asetigerous hind tibial pectens, Neazoniidae [Szwedo, 2007] and Dorytocidae [Emeljanov, Shcherbakov, 2018] show other features in common with perforissids and mimarachnids. Subbrachypterous flightless Jubisentidae were described as related to Perforissidae [Zhang et al., 2019]. The new subfamily combines characters of typical jubisentids with a few perforissid characters and so bridges the gap between the two families.

How to cite this article: Shcherbakov D.E. 2020. The earliest fully brachypterous auchenorrhynchan from Cretaceous Burmese amber (Homoptera: Fulgoroidea: Jubisentidae) // Russian Entomol. J. Vol.29. No.1. P.6 -11. doi: 10.15298/rusentj.29.1.02 
The holotype female of the new species is extremely brachypterous, with tegmina covering only the mesoand metanotum. Such advanced brachyptery is common in planthoppers (Delphacidae, Dictyopharidae Orgeriinae, Caliscelidae) and leafhoppers, as well as in some groups of true bugs [Schuh, Slater, 1995], occurs as a rare exception in froghoppers [Fennah, 1966], and is unknown in cicadas, treehoppers and Sternorrhyncha. Brachypterous leafhoppers and planthoppers have been reported from Eocene Baltic amber (Szwedo, 2002, fig. 24; Szwedo, Stroiński, 2013; Dietrich, Gonçalves, 2014), but appear to remain unknown from pre-Cenozoic strata. Therefore, the discovery of a strongly brachypterous planthopper in Cretaceous amber is of considerable interest. It seems to be the first record of a brachypterous Auchenorrhyncha from as far back as the Mesozoic.

In its general habitus, short veinless tegmina, and foliaceous fore and mid legs the new genus is similar to some Caliscelidae, especially Caliscelis de Laporte, 1833. Caliscelids sometimes show striking sexual dimorphism, with males mimicking jumping spiders [O'Brien, 1967] or ants [Gnezdilov, 2019]. Perforissidae also share many traits with Caliscelidae, though these two families are not closely related [Shcherbakov, 2007a].

Wing reduction occurs in Auchenorrhyncha feeding on herbs and forbs, but not in their arboreal relatives [Waloff, 1983]. Among grass feeding Auchenorrhyncha, flightless brachypterous forms are common in permanent habitats and rare in temporary ones [Denno et al., 1991; Novotný, 1994]. Caliscelidae and Delphacidae largely feed on grasses and often display wing dimorphism; the macropterous form can be very rare, for example, in Caliscelidae. The new species may be wing dimorphic as well. Its hypothetical macropterous form is expected to retain such diagnostic characters of the new subfamily as sensory pits, reduced setation, and modified head structure to be easily distinguishable from Jubisentinae, which are currently known by two subbrachypterous flightless species. Flightless Jubisentidae presumably fed on some herbaceous host plants, such as grass-like monocots of the Burmese amber flora [Poinar, 2004]. The new genus may be one of the earliest planthoppers associated with grasses, and its extreme brachyptery agrees with the assumption that some permanent grassy patches already existed in the mid-Cretaceous. Plants with vegetative morphology of grasses (Graminophyllum) are known since the Neocomian [Krassilov, 1982].

Nymphs of most planthopper families have sensory pits, forming rows and groups associated with carinae [Bräunig et al., 2012] and homologous to setigerous pits of Cicadomorpha [Emeljanov, 2001]. The sensory pits, supposed to be receptors of atmospheric humidity [Sulc, 1928], persist in adults of some planthopper taxa, especially in xerophiles or hygrophiles. The numerous sensory pits of adult perforissids suggest that they have lived in habitats with highly variable and/or extreme humidity [Shcherbakov, 2007a], like littoral environments with xeromorphic bennettite-brachyphyll com- munities, rich in proangiosperms and considered to have been the cradle of angiosperms [Krassilov, 1997]. The new genus of Jubisentidae, similar to perforissids in having numerous sensory pits, could also have inhabited herbaceous vegetation near the sea coast, on river banks, rocky outcrops, etc.

Various examples of camouflage and mimicry in insects from Burmese and other Cretaceous ambers indicate widespread occurrence of these phenomena in the Mesozoic tropics [Wang et al., 2016; Chen et al., 2019; Vršanský et al., 2019; etc.]. Some Mesozoic hoppers showing such camouflage elements as bizarre outgrowths, long head processes, foliaceous legs fringed with setae, or undulating margins of tegmina supposedly mimicked buds, strobiles or thorns of their host plants [Shcherbakov, 2011; Emeljanov, Shcherbakov, 2018], or adhered closely to the bark of host trees [Jiang et al., 2019]. Jubisentids also display elements of cryptic appearance [Zhang et al., 2019].

Some present-day hoppers, especially flightless, are masters of camouflage. Ground-dwelling subbrachypterous Myerslopiidae leafhoppers encrust their strangely shaped, ridged bodies with soil particles to blend into their environment [Rakitov, 2015]. Some brachypterous planthoppers, such as Risius Stål, 1859 (e.g. $R$. gibbus Fennah, 1967, R. palamedes Fennah, 1967, Fulgoridae) and Kazerunia Dlabola, 1974 (e.g. K. leguaniforma Dlabola, 1977, Tropiduchidae), have dorsal humps, ridges and lobes and resemble small lumps of dirt. The flattened and slender forms of Dorycephalini and Hecalini leafhoppers imitate grass seeds or twigs [Hamilton, 2000]. Brachypterous Orgeriinae planthoppers (Dictyopharidae) taking an unusual upright posture with their long legs stretched out [Ball, 1909] supposedly mimic the achenes of Asteraceae [Oshanin, 1913: 9] or salticid spiders [Emeljanov, 1980: 44]. The new apterous Burmese amber jubisentid appears camouflaged due to its serrated dorsal outline with transverse ridges, long foliaceous fore and mid legs fringed with setae, and brown colouration. On account of its long legs, it was likely mimicking spiders, seeds or plant debris rather than soil. A camouflage of this kind can be effective both on the host plant and near the ground.

The holotype of the new species is deposited at Borissiak Paleontological Institute, Russian Academy of Sciences, Moscow (PIN). Photographs were taken using a Leica M165C stereomicroscope with a Leica DFC425 digital camera and z-stacked with Helicon Focus 7.0. Nomenclature of the planthopper cranium is given after Anufriev and Emeljanov [1988].

\section{Family Jubisentidae Zhang et al., 2019}

REVISED DIAGNOSIS. Small and compact planthoppers, at least legs with long setae. Eumetope and clypeus with median carina; clypeus strongly raised, without lateral carinae; rostrum extending beyond hind coxae, apical segment longer than wide. Ocelli absent. Pronotum with anterior margin produced beyond eye midlength, lateral margin posterior to eyes very short, posterior margin shallowly incised. Subbrachypterous or brachypterous, venation of tegmina 


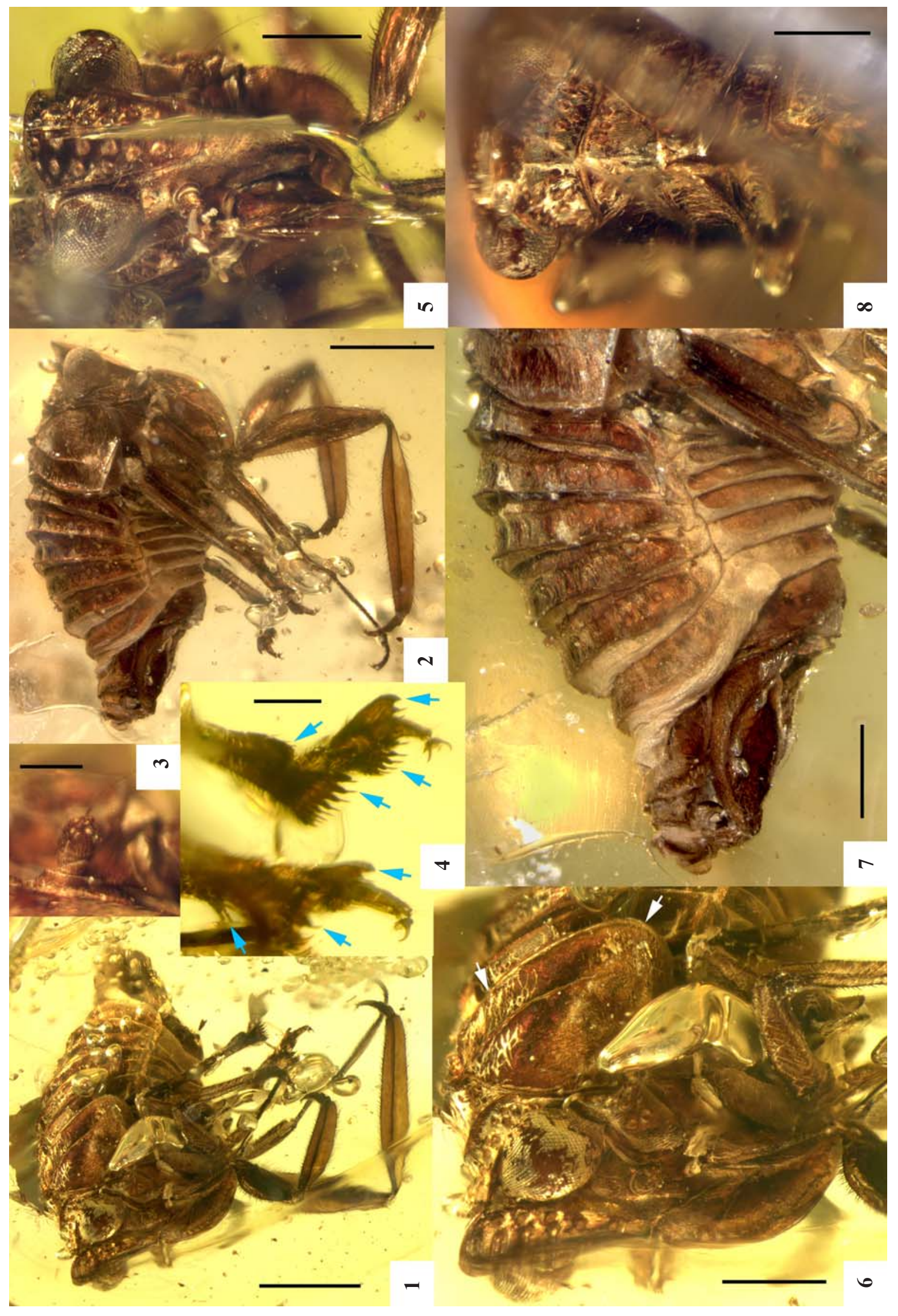


indistinct; tegula, claval suture and hind wing absent. Hind tibia without lateral teeth; all apical pectens of hind leg uniserial, of several teeth with subapical setae. Female abdomen short, ovipositor long, ensiform, its base about midlength of abdomen.

COMPOSITION. Two subfamilies.

Subfamily Jubisentinae Zhang et al., 2019, stat.n.

TYPE GENUS Jubisentis Zhang et al., 2019.

DIAGNOSIS. Body, legs and tegmina covered with long setae. Sensory pits absent at adult stage. Eumetope with median carina and weak submedian carinae, separated from coryphe by sandglass-shaped acrometope bordered with low carinae. Pronotum with median carina incomplete anteriorly; mesonotum without median carina. Subbrachypterous. Hind legs longest. Male pygophore elongate. Ovipositor projecting beyond anal tube.

COMPOSITION. Type genus and Furtivirete Zhang et al., 2019.

\section{Subfamily Psilarginae Shcherbakov, subfam.n.}

TYPE GENUS. Psilargus Shcherbakov, gen.n.

DIAGNOSIS. Legs with long setae, body bare. Sensory pits large, numerous at adult stage. Eumetope without submedian carinae, separated from coryphe by single high carina (no acrometope). Pronotum with median carina complete; mesonotum with median carina. Strongly brachypterous. Fore legs longest. Ovipositor not projecting beyond anal tube.

COMPOSITION. Type genus.

REMARKS. The new subfamily shows a few characters in common with Perforissidae - bare body with large sensory pits in adults, and eumetope without submedian carinae. However, this subfamily fits Jubisentidae in the other characters: clypeus with high median crest, shape of pronotum, foliaceous legs fringed with long setae, wing reduction and the absence of tegula, claval suture and ocelli. Jubisentinae also share one character with Perforissidae - the presence of the acrometope.

\section{Psilargus Shcherbakov, gen.n.}

TYPE SPECIES. Psilargus anufrievi Shcherbakov, sp.n.

DIAGNOSIS. Besides characters listed in subfamily diagnosis, differs from two known genera of nominate subfamily in the following features, mainly associated with brachyptery. Dorsal outline serrated in profile, with upcurved posterior edges of body segments and transverse ridges on tegmen and abdominal tergites. Lateral margins of pronotum exposed (overlapped by eyes reaching bases of tegmina in other jubisentid genera). Mesonotum triangular with apex truncate and upcurved (acute in other jubisentids). Fore legs longer than body (shorter). Hind tibiae slender with fin-like lateral lobe distally (foliaceous for entire length in other jubisentids). Subapical setae of hind leg pectens acuminate, of acutella type (slightly inflated, somewhat platella-like in other jubisentids); $2^{\text {nd }}$ tarsal pecten with two outermost teeth asetigerous.

COMPOSITION. Type species.
ETYMOLOGY. From the Greek psilos (bare, smooth, naked), referring to the reduction of wings and body setae, and Argos (hundred-eyed guardian of Io), referring to dozens of round sensory pits; gender masculine.

\section{Psilargus anufrievi Shcherbakov, sp.n.} Figs 1-8.

MATERIAL. Holotype brachypterous female PIN 5608/106 Burmese amber, Hukawng Valley, Kachin State, Myanmar; midCretaceous (Albian-Cenomanian).

DESCRIPTION. Body $3.6 \mathrm{~mm}$ long, compact, ovoid, somewhat compressed laterally, especially abdomen. Dorsal outline serrated in profile due to carina at head apex, raised or upcurved posterior edges of body segments, and transverse ridges on tegmina and abdominal tergites $\mathrm{I}-\mathrm{V}$. Dorsum without conspicuous longitudinal carinae or setae, finely longitudinally wrinkled, with one patch of transverse wrinkles in anterolateral part of tegmen. Head brown, dorsum unevenly suffused with brown, legs dark brown with pale spot under fore knee, sternites I-VI pale brown, sternite VII and ovipositor darker.

Head $1.3 \mathrm{~mm}$ wide, $1.9 \mathrm{~mm}$ high. Coryphe transverse, 3.5 times as wide as long, rising towards angulate anterior margin, with median carina. Eumetope 1.8 times as long as wide, gradually narrowed ventrally, twice as wide dorsally as ventrally, slightly tectiform in cross section, with median carina. Boundary of eumetope and coryphe arched in facial view, formed by single high carina faced dorsad. Each half of eumetope with about 15 sensory pits in two irregular rows, medial row of larger pits reaching level of antennae, lateral row of smaller pits restricted to dorsal half of eumetope. Clypeus as long as eumetope, with deeply arched median crest and oblique loroclypeal sutures not reaching it. Eyes large, ovoid. Antenna short, scape extremely short dorsally and slightly longer anteroventrally; pedicel ovoid, 1.5 as long as wide, with at least 12 sensory plaque organs. Rostrum 1.1 $\mathrm{mm}$ long, slender, reaching base of abdomen, with apical segment longer than wide.

Pronotum nearly 2.5 times as wide as long, with median carina; anterior margin trapezoidal, projecting forwards between eyes and somewhat overlapping coryphe; lateral margin very short, posterior margin $\mathrm{W}$-shaped with shallow median incision; each half with nearly 15 sensory pits in two rows, anterior row of smaller pits and posterior row of larger pits with few smaller pits displaced posteriorly and forming rudimentary third row; pectoral lobe with 7 pits. Mesonotum subtriangular with apex truncate and upcurved, 1.7 times as long as wide, each half with 3 sensory pits anterolaterally; mesopleura small. Tegmina strongly brachypterous, truncate, wider than long, covering only thorax (abdominal tergite I free), not meeting with their commissural margins, without traces of veins, with narrow epipleuron separated by lateral carina, and transverse posterior submarginal ridge aligned with apex of mesonotum; metapleura large, anepisternum very dark, convex.

Coxae, femora and tibiae fringed along ribs with dark, erect, long and shorter setae. Coxae long, fore and mid coxae

Figs 1-8. Psilargus anufrievi gen. et sp.n., holotype female, Burmese amber: 1 - habitus, anterolateral view; 2 - habitus, lateral view; 3 - antenna, anterior view; 4 - distal parts of hind legs (arrows - tibial lobe and apical pectens); 5 - head, frontal view; 6 - head and thorax, anterolateral view (arrows - margin of tegmen); 7 - abdomen, lateral view; 8 - head and thorax, dorsal view. Scale bars: $1-2-$ $1 \mathrm{~mm} ; 3-4-0.2 \mathrm{~mm} ; 5-8-0.5 \mathrm{~mm}$.

Рис. 1-8. Psilargus anufrievi gen. et sp.n., голотип, самка, бирманский янтарь: 1 - общий вид, спереди-сбоку; 2 - общий вид, сбоку; 3 - антенна, спереди; 4 - вершины задних ног (стрелки — лопасть на голени и гребни); 5 - голова, спереди; 6 - голова и грудь, спереди-сбоку (стрелки - край элитры); 7 - брюшко, сбоку; 8 - голова и грудь, сверху. Длина масштабной линейки: $1-$ $2-1$ мм; 3-4-0,2 мм; 5-8-0,5 мм. 
about as long as thorax height above them; fore coxae with outer edge foliaceous. Fore legs $3.8 \mathrm{~mm}$ long. Fore femora and tibiae foliaceous with outer margin more convex than inner margin; tarsi of subequal segments, $1^{\text {st }}$ segment flattened laterally and highest, $3^{\text {rd }}$ slender and longest. Mid legs $2.6 \mathrm{~mm}$ long, slender, femora flattened, tibiae narrow foliaceous, tarsi slender with $3^{\text {rd }}$ segment longest. Hind legs $3.4 \mathrm{~mm}$ long. Hind trochanter largely membranous, with dark hook-like sclerotization along anteroventral side. Hind tibia quadrilateral, slightly curved, twisted distally, without lateral teeth, with fin-like lateral lobe on posterodorsal rib subapically. Apices of hind tibia and $1-2^{\text {nd }}$ tarsomeres swallow-tailed with apical pectens of numerous setigerous teeth. Tibial pecten arched in apical view, all 8 teeth with long subapical setae. $1^{\text {st }}$ tarsomere longest with pecten semicircular in apical view, of 10 teeth, outermost teeth with shortened subapical setae. $2^{\text {nd }}$ tarsomere shortest, compressed laterally, inserted into 1st, with pecten deeply $\mathrm{V}$-shaped in apical and dorsal views, of 14 teeth, both outermost teeth widened, without subapical setae. $3^{\text {rd }}$ tarsomere slender. Claws simple, slender, strongly curved and tapered to apices; arolium well developed, wide, much shorter than claws.

Abdomen $2.6 \mathrm{~mm}$ long, tergites and sternites deeply arched or almost V-shaped. Tergites I-VI short with raised posterior margin, $\mathrm{I}-\mathrm{V}$ also with anterior submarginal ridge and in each half with 1(2) submedian sensory pit and lateral row of several pits (I $-1, \mathrm{II}-4$, III -5 , IV $-6, \mathrm{~V}-3$ ); tergite VI without pits. Spiracles visible as dark dots on membranous laterotergites near anterolateral angles of tergites I-V; laterotergite VI without spiracle, not separated from sternite. Sternites I-VI shorter than tergites. Tergites VIIVIII apparently somewhat reduced and/or hidden between membranous folds; sternite VII much longer, more convex and sclerotized than preceding, with shallow submedian posterior incisions. Segment IX (pygophore) elongate, tapered caudally, with anterior margin deeply incised, posterior submarginal ridge and lateral row of 5 sensory pits beyond it; ventral side concave, housing ovipositor. Ovipositor well developed, $1.2 \mathrm{~mm}$ long, occupying half of abdomen length. 3 rd valvulae broad, lancet-shaped, consisting of outer subcylindrical rachis downcurved and tapered to acutely rounded apex, and lip-like blades with arched edges directed ventromedially, meeting along midline and leaving only bases of cutting inner valvulae exposed. Segment X (anal tube) as long as wide; dorsal side roof-shaped with median carina; lateral carinae with rectangular acuminate posterior angles; apical side with paired drop-shaped epiprocts and short anal style.

ETYMOLOGY. The species is dedicated to the memory of a Russian expert in Auchenorrhyncha, Georgy A. Anufriev (1943-2017).

Acknowledgements. I am deeply indebted to Alexey Bashkuev (PIN) for attracting my attention to this fossil, Alexander Emeljanov (Zoological Institute RAS, St.-Petersburg) and Roman Rakitov (PIN) for valuable suggestions and comments on the manuscript. The study was supported by the RFBR project 18-04-00322.

\section{References}

Anufriev G.A., Emeljanov A.F. 1988. [Suborder Cicadinea (Auchenorrhyncha)]//Opredelitel' nasekomykh Dal'nego Vostoka SSSR. Vladivostok. Vol.2. P.12-495 [in Russian].

Ball E.D. 1909. Some remarkable new leafhoppers of the family Fulgoridae // Proc. Biol. Soc. Wash. Vol.22. P.197-204.
Bräunig P., Krumpholz K., Baumgartner W. 2012. Sensory pits Enigmatic sense organs of the nymphs of the planthopper Issus coleoptratus (Auchenorrhyncha, Fulgoromorpha) // Arthropod Struct. Dev. Vol.41. P.443-458.

Chen J., Wang B., Zhang H., Jiang H., Jiang T., An B., Zheng Y., Wang X. 2019. A remarkable new sinoalid froghopper with probable disruptive colouration in mid-Cretaceous Burmese amber (Hemiptera, Cicadomorpha) // Cretac. Res. Vol.98. P.9-17.

Denno R.F., Roderick G.K., Olmstead K.L., Dobel H.G. 1991. Density-related migration in planthoppers (Homoptera: Delphacidae) // Am. Nat. Vol.138. P.1513-1541.

Dietrich C.H., Gonçalves A.C. 2014. New Baltic amber leafhoppers representing the oldest Aphrodinae and Megophthalminae (Hemiptera, Cicadellidae) // Eur. J. Taxon. Vol.74. P.1-13.

Emeljanov A.F. 1980. [Phylogeny and evolution of subfamily Orgeriinae (Homoptera, Dictyopharidae)] // Chteniya pamyati N.A. Kholodkovskovo. Vol.32. P.1-96 [In Russian].

Emeljanov A.F. 2001. Larval characters and their ontogenetic development in Fulgoroidea (Homoptera, Cicadina) // Zoosyst. Ross. 2000. Vol.9. P.101-121.

Emeljanov A.F., Shcherbakov D.E. 2018. The longest-nosed Mesozoic Fulgoroidea (Homoptera): A new family from mid-Cretaceous Burmese amber // Far East. Entomol. Vol.354. P.1-14.

Fennah R.G. 1966. A brachypterous Cercopid from the Ruwenzori range, representing a new genus and species (Homoptera: Cercopoidea) // Proc. R. Entomol. Soc. London. Ser.B. Vol.35. P.72-74.

Gnezdilov V.M. 2019. A new species of the myrmecomorphic planthopper genus Formiscurra (Fulgoroidea: Caliscelidae) from Ethiopia // Acta Entomol. Mus. Natl. Pragae. Vol.59. P.17-22.

Hamilton K.G.A. 2000. Five genera of new-world "shovel-headed" and "spoon-bill" leafhoppers (Hemiptera: Cicadellidae: Dorycephalini and Hecalini) // Can. Entomol. Vol.132. P.429-503.

Jiang T., Szwedo J., Wang B. 2019. A unique camouflaged mimarachnid planthopper from mid-Cretaceous Burmese amber // Sci. Rep. Vol.9. P.1-11.

Krassilov V.A. 1982. Early Cretaceous flora of Mongolia // Palaeontographica B. Bd.181. S.1-43.

Krassilov V.A. 1997. Syngenesis of xeromorphic plant communities in the Late Paleozoic to Early Cenozoic // Paleontol. J. Vol.31. P.125-134

Luo C., Jiang T., Wang B., Xiao C. 2020. A new species of Burmissus (Hemiptera: Fulgoromorpha: Mimarachnidae) from mid-Cretaceous Burmese amber // Cretaceous Research. Vol.110 [in press].

Novotný V. 1994. Relation between temporal persistence of host plants and wing length in leafhoppers (Hemiptera: Auchenorhyncha) // Ecol. Entomol. Vol.19. P.168-176.

O’Brien L.B. 1967 Caliscelis bonellii (Latreille), a European genus of Issidae new to the United States (Homoptera: Fulgoroidea) // Pan-Pac. Entomol. Vol.43. P.130-133.

Oshanin V.T. 1913. Insectes Hémiptères (Insecta Hemiptera). Cixiidae: Orgeriaria // Faune de la Russie et des Pays Limitrophes fondée principalement sur les collections du Musée Zoologique de l'Académie Impériale des Sciences de St.-Pétersbourg. Vol.3. No.1. P.i-iii, 4-113 [in Russian].

Perkovsky E.E., Olmi M., Müller P., Martynova K.V. 2019. A review of the genus Hybristodryinus Engel, 2005 (Hymenoptera, Dryinidae) from mid-Cretaceous Burmese amber, with a discussion on its phylogenetic significance // Cretac. Res. Vol.99. P.169189.

Poinar G.O. Jr. 2004. Programinis burmitis gen. et sp. nov., and $P$. laminatus sp. nov., early Cretaceous grasslike monocots in Burmese amber // Aust. Syst. Bot. Vol.17. P.497-504.

Poinar G.O. Jr., Buckley R. 2008. Cretacifilix fungiformis gen. and sp. nov., an eupolypod fern (Polypodiales) in Early Cretaceous Burmese amber // J. Bot. Res. Inst. Texas. Vol.2. P.1175-1182.

Poinar G. Jr., Lambert J.B., Wu Y. 2007. Araucarian source of fossiliferous Burmese amber: Spectroscopic and anatomical evidence // J. Bot. Res. Inst. Texas. Vol.1. P.449-455.

Rakitov R. 2015. Observations on the biology and anatomy of Myerslopiidae (Hemiptera, Membracoidea) // Psyche. Article ID 898063.

Schuh R.T., Slater J.A. 1995. True Bugs of the World (Hemiptera: Heteroptera): Classification and Natural History. Ithaca: Cor- 
nell University Press. 336 pp.

Shcherbakov D.E. 2000. The most primitive whiteflies (Hemiptera; Aleyrodidae; Bernaeinae subfam. nov.) from the Mesozoic of Asia and Burmese amber, with an overview of Burmese amber hemipterans // Bull. Nat. Hist. Mus. London (Geol.). Vol.56. P.29-37.

Shcherbakov D.E. 2007a. An extraordinary new family of Cretaceous planthoppers (Homoptera: Fulgoroidea) // Rus. Entomol. J. Vol.16. P.139-154

Shcherbakov D.E. 2007b. Mesozoic spider mimics - Cretaceous Mimarachnidae fam.n. (Homoptera: Fulgoroidea) // Rus. Entomol. J. Vol.16. P.259-264.

Shcherbakov D.E. 2011. New and little-known families of Hemiptera Cicadomorpha from the Triassic of Central Asia - early analogs of treehoppers and planthoppers // Zootaxa. Vol.2836. P.1-26.

Shcherbakov D.E. 2017. First record of the Cretaceous family Mimarachnidae (Homoptera: Fulgoroidea) in amber // Rus. Entomol. J. Vol.26. P.389-392.

Song Z.S., Xu G.H., Liang A.P., Szwedo J., Bourgoin T. 2019. Still greater disparity in basal planthopper lineage: A new planthopper family Yetkhatidae (Hemiptera, Fulgoromorpha, Fulgoroidea) from mid-Cretaceous Myanmar amber // Cretac. Res. Vol.101. P.47-60.

Šulc K. 1928. Die Wachsdrüsen und ihre Produkte bei den Larven der Cixiinen (Homoptera) // Biol. Spisy Vysoké Školy Zvěrol., Brno. Vol.7. P.149-180.

Szwedo J. 2002. Amber and amber inclusions of planthoppers, leafhoppers and their relatives (Hemiptera, Archaeorrhyncha et Clypaeorrhyncha) // Denisia 04, zugleich Kataloge des OÖ. Landesmuseums. N.F. Nr.176. P.37-56.

Szwedo J. 2004. Niryasaburnia gen. nov. for 'Liburnia' burmitina Cockerell, 1917, from Cretaceous Myanmar (Burmese) amber (Hemiptera, Fulgoromorpha: Achilidae) // J. Syst. Palaeontol.
Vol.2. P.105-107.

Szwedo J. 2007. Nymphs of a new family Neazoniidae fam. n. (Hemiptera: Fulgoromorpha: Fulgoroidea) from the Lower Cretaceous Lebanese amber. Afr. Invertebr. Vol.48. P.127-143.

Szwedo J., Stroiński A. 2013. An extraordinary tribe of Tropiduchidae from the Eocene Baltic amber (Hemiptera: Fulgoromorpha: Fulgoroidea) // Zootaxa. Vol.3647. P.371-381.

Vršanský P., Bechly G., Zhang Q., Jarzembowski E.A., Mlynský T., Šmídová L., Barna P., Kúdela M., Aristov D., Bigalk S., Krogmann L., Li L., Zhang Q., Zhang H., Ellenberger S., Müller P., Gröhn C., Xia F., Ueda K., Vd’ačný P., Valaška D., Vršanská L., Wang B. 2018. Batesian insect-insect mimicry-related explosive radiation of ancient alienopterid cockroaches // Biologia. Vol.73. P.987-1006.

Waloff N. 1983. Absence of wing polymorphism in the arboreal, phytophagous species of some taxa of temperate Hemiptera: an hypothesis // Ecological Entomology. Vol.8. No.2. P.229-232.

Wang B., Xia F., Engel M.S., Perrichot V., Shi G., Zhang H., Chen J., Jarzembowski E.A., Wappler T., Rust, J. 2016. Debriscarrying camouflage among diverse lineages of Cretaceous insects // Science Advances. Vol.2. No.6. e1501918.

Westerweel J., Roperch P., Licht A., Dupont-Nivet G., Win Z., Poblete F., Ruffet G.; Swe H.H., Thi M.K., Aung D.W. 2019. Burma Terrane part of the Trans-Tethyan arc during collision with India according to palaeomagnetic data // Nat. Geosci. Vol.12. P.863-868.

Zhang X., Ren D., Yao Y. 2017. A new species of Foveopsis Shcherbakov (Hemiptera: Fulgoromorpha: Fulgoroidea: Perforissidae) from mid-Cretaceous Burmese amber // Cretac. Res. Vol.79. P.35-42.

Zhang X., Ren D., Yao Y. 2019. A new family Jubisentidae fam. nov. (Hemiptera: Fulgoromorpha: Fulgoroidea) from the mid-Cretaceous Burmese amber // Cretac. Res. Vol.94. P.1-7. 